\title{
IMPLEMENTATION OF DIGITAL LITERACY COMPETENCY AT SENIOR HIGH SCHOOL IN JAKARTA
}

\author{
Floren Agnesia ${ }^{1} \bowtie$, Ratna Dewanti ${ }^{2}$, Darmahusni ${ }^{3}$ \\ 1,2,3 Language Education Department, State University of Jakarta, Indonesia.
}

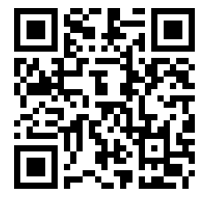

Received 11August 2021

Accepted 01 September 2021

Published 21 September 2021

\section{CorrespondingAuthor}

Floren Agnesia,

florenagnesia_9905817003@mhs.unj.ac.id

\section{DOI 10.29121/ijetmr.v8.i9.2021.1026}

Funding: This research received no specific grant from any funding agency in the public, commercial, or not-for-profit sectors.

Copyright: (C) 2021 The Author(s). This is an open access article distributed under the terms of the Creative Commons Attribution License, which permits unrestricted use, distribution, and reproduction in any medium, provided the original author and source are credited.

\section{ABSTRACT}

The development and implementation of information and technology in education, give an impact to literacy. The implementation of information and technology with literacy is known as digital literacy. Digital literacy not only talks about the skill or competency of using technology as a teacher in the learning process, but how school as a formal education institution can help the students to have digital literacy competency since this skill is needed by the students and teachers who are imposed by the technology as an impact of the pandemic. Schools not only have a responsibility to educate students about digital literacy competency in the learning process, but in all the school aspects must support the implementation of digital literacy. This research wants to explore how digital literacy competency has been implemented at senior high school level in Indonesia. Therefore, this descriptive qualitative research objective is to explore the digital literacy competency implemented at Citra Kasih School in Indonesia. The data collection techniques used in this research were observing and interviewing the principal by asking questions that had passed the validity test. Following the digital literacy competency which was set by Indonesian Ministry of Education and Culture (2017), this research explored the implementation of digital competency into three bases, class based, school environment based, and community based. From the research, it can be concluded that Citra Kasih Senior High School has applied three bases of digital literacy competency indicator at school. In the class based, Citra Kasih Senior High School has attended digital literacy training, applied and utilized digital literacy, and understood how to use digital media and the internet. Based on the school environment Sekolah Citra Kasih High School has implemented digital literacy in reading references, book borrowing frequencies, school activity, school policy. School service, and information presentation. However, on community based, Citra Kasih Senior High School has implemented digital literacy in facilities and infrastructure and in the involvement of parents and institutions.

Keywords: Implementation, Competency, Digital Literacy, Jakarta

\section{INTRODUTION}

Many people define literacy as reading and writing skills. Literacy is similar to language skill. As the time goes by and the development of technology, literacy can be implemented and integrated to other things which are more specific. An integration between literacy and technology also known as digital literacy. 
Digital literacy is a specific set of technical skills, such as skills to use software or operate hardware (Casey et al. (2009). Ministry of Education and Culture in Indonesia (2017) defines digital literacy is knowledge and skills to use digital media, communication tools, or networks in finding, evaluating, using, creating information, and utilizing it in a healthy, wise, intelligent, careful, precise, and lawabiding manner in order to foster communication and interaction in everyday life. Digital literacy is no longer limited to the use of technology alone, but also refers to ideas and mindsets contained in certain skills and competencies (Bawden (2001).

Digital literacy and related skills will be the foundation and basic skills for survival in this highly competitive world (Phuapan et al. (2016). It is very important to the school as an educational institution for implementing digital literacy skills such as basic skills for students to face competition in the future. The implementation of digital literacy in the teaching and learning process in schools is a challenge for schools in general and teachers in particular in the 21st century (Ferrari, 2013).

According to (Rodliyah (2018), the need to collaborate with technology in the learning process in the classroom, with regard to the emergence of new literacy as an impact of 21st century learning is currently happening. The ability to master these competencies provides benefits in this modern era because the lack of digital media literacy education will cause a terrible phenomenon in Indonesia (Supratman and Wahyudin (2017). As a formal educational institution in Indonesia, schools are expected to be able to implement these digital literacy skills thoroughly and completely. As a reference for the implementation of digital literacy in Indonesia, the Ministry of Education and Culture in Indonesia has compiled digital literacy competency standards in Indonesia.

According to Indonesian Minister of Culture and Education (2017) there are three aspects of digital literacy praxis in schools, namely classroom-based, schoolbased culture, and community-based. Class-based digital literacy is digital literacy carried out in the classroom, namely digital literacy carried out in the learning process and digital literacy carried out by school members. School culture-based digital literacy is digital literacy carried out in the school environment, in the form of a series of activities and school services that support school operations. The indicator of digital literacy competency by Indonesian Ministry of Education and Culture will be shown in this table below:

\begin{tabular}{|c|c|c|}
\hline \multirow{3}{*}{ Class Based } & 1. & $\begin{array}{l}\text { Number of digital literacy training attended by the principal, teachers, } \\
\text { and education personnel. }\end{array}$ \\
\hline & 2. & $\begin{array}{l}\text { Intensity of application and utilization using digital device in learning } \\
\text { activities }\end{array}$ \\
\hline & 3. & $\begin{array}{l}\text { Level of understanding of principal, teachers, education staff, and } \\
\text { students using digital media and internet. }\end{array}$ \\
\hline \multirow{6}{*}{$\begin{array}{c}\text { School } \\
\text { Culture Based }\end{array}$} & 1. & $\begin{array}{l}\text { Number of variations of reading materials and digital-based teaching } \\
\text { aids }\end{array}$ \\
\hline & 2. & Frequency of borrowing digital themed books \\
\hline & 3. & Number of activities in schools that utilize technology and information \\
\hline & 4. & $\begin{array}{l}\text { Number of presentations of school information using digital media or } \\
\text { web sites }\end{array}$ \\
\hline & 5 . & $\begin{array}{l}\text { Number of school policies regarding the use and utilization of } \\
\text { information and communication technology in the school environment }\end{array}$ \\
\hline & & $\begin{array}{l}\text { The level of utilization and application of information and } \\
\text { communication technology in terms of school services (e.g. e-report, } \\
\text { financial management, dapodik, utilization of student data, school } \\
\text { profiles, and so on). }\end{array}$ \\
\hline
\end{tabular}




$\begin{array}{lll}\begin{array}{c}\text { Community } \\ \text { Based }\end{array} & \text { 1. } & \begin{array}{l}\text { Number of facilities and infrastructure that support digital literacy at } \\ \text { school }\end{array} \\ \text { 2. } & \begin{array}{l}\text { Level of involvement of parents, community, and institutions in the } \\ \text { development of digital literacy }\end{array}\end{array}$

Digital literacy competency indicator which has been reviewed and arranged by Indonesian Ministry of Education and Culture will be used as a reference in this research to explore digital literacy competency that has been applied in senior high school level.

Citra Kasih High School is one of the schools that has implemented digital literacy in the learning process. This can be seen from the implementation of the Mid-Semester Examination and the Final Semester Examination which are carried out online using each student's laptop. Every student is required to bring a laptop to school to realize digital learning and reduce paper use.

Recognizing the importance of implementing digital literacy in education, several studies both abroad and in Indonesia have been carried out with different levels of education. In the city of Dublin - Ireland, (Casey et al. (2009) conducted a study entitled Digital Literacy in Primary School (DLIPS) in four primary schools. Shifting to the Asian region, especially Thailand, a research entitled An Analysis of Digital Literacy Skills among Thai University Seniors was conducted by (Phuapan et al. (2016) with the aim of determining which digital skills are most widely used in the use of technology, communication tools to access, manage, integrate, evaluate, create and communicate information in society.

In Indonesia, literacy research has also been carried out or developed at the school level. Research at the secondary level was carried out with the title The Praxis of Digital Literacy in the EFL Classroom: Digital-Immigrant VS Digital-Native Teacher (Kurniawati et al. (2018) to investigate the use of digital literacy by teachers across generations in English classes . Other research on digital literacy was also carried out in non-formal education with the title Digital Literacy with EFL Student Teachers: Exploring Indonesian Student Teacher's Initial Perception About Integrating Digital Technologies Into a Teaching Unit (Lathipatud and Zuhdi (2018) . Most research on digital literacy is related to the teaching and learning process that is currently being conducted online. However school is not only about the learning process itself, there are some supporting aspects such as school culture and community in the school. So, this research purpose is to explore how digital literacy competencies are applied in school, not only in the learning process but also in the school culture and school community.

\section{METHODS}

The approach used in this research is descriptive qualitative which aims to explore the implementation of digital literacy competencies at Citra Kasih High School in Indonesia by referring to the digital literacy competency indicators that have been set by Indonesian Ministry of Education and Culture (2017). The research was conducted at Citra Kasih High School, located in West Jakarta. This research was conducted from January 2021 to March 2021.

To obtain complete and comprehensive data, the researchers conducted interviews with three participants, they are English teachers and principal of SMA Citra Kasih. Interviews were conducted by asking a number of questions that had been tested for validity by experts. All of the questions were adapted from Indonesian Ministry of Education and Culture digital literacy competency. The interview process was carried out virtually considering the current conditions that did not allow face-to-face meetings. 
Data collection techniques used to obtain accurate and comprehensive data, researchers interviewed teachers and vice principals of SMA Citra Kasih in the form of virtual meetings while observation activities were carried out physically and in virtual form. The results of interviews and observations obtained by the researchers were then used as data in the study. Then the data obtained from the results of interviews and observations are parsed and described in descriptive form to investigate the practice of digital literacy carried out in the school environment at Citra Kasih High School.

\section{RESULTS AND DISCUSSION}

\subsection{CLASS BASED}

Indonesian Ministry of Education and Culture (2017) stated that the application of digital literacy competencies based on class has three indicators, they are the number of digital literacy training attended, intensity of application and utilization of digital literacy, and level of understanding of principal, teachers, and staff in using media digital and internet.

\section{Digital Literacy Training Attended}

Citra Kasih High School is one the schools that collaborates with Indonesian Ministry of Education and Culture along with REFO Indonesia in supporting digital literacy competencies of Indonesian teachers. Citra Kasih High School's principal said that she always encourages all of the teachers to join the webinar from REFO Indonesia to enrich the teacher.

To support the teachers more specifically based on the case that happened in Citra Kasih School, the principal created Teacher Personality Development (TPD) as a digital training for teacher from teacher to share their personal experience in applying digital media to their classroom. This training is setted once a month to help the teacher with the digital problem in preparing the material or deliver the material using a creative media digital when teaching. This training must be attended by all the teachers and staff.

\section{Application and Utilization of Digital Literacy}

Applying and utilizing digital literacy in Citra Kasih Senior High School is not a new thing. The principal said that before the pandemic they already asked the students to bring and use laptops at school. Almost all the subjects at school use laptops. However since this pandemic, the application and utilization of digital literacy is more developed.

Since the pandemic, all of the learning process has been held virtually using digital devices using zoom and gmeet. All of the books and worksheets are online using a certain application or website. Almost all teachers' resources are taken from valid resources. Now the teachers become facilitators that support and guide the students since all of the material has been provided on the internet. Google and Youtube are now friends.

\section{Understanding of School Members in Using Media Digital \& Internet}

Citra Kasih Senior High School Principal said they didn't have any specific measurement to know the understanding of all school members in using media digital and internet because all the school members always tried to help each other if they got a problem with the digital media and internet. All the school activities during this pandemic have been held online and there is no big problem that they face. Problem is a must, but the ICT teams are always there to solve the problem.

Every school member has their own responsibility so that all the applications and digital media used will be different to each other. "When they can do and 
complete all the jobs easily, can I say that they have understood and are familiar with using digital media and the internet?" said Citra Kasih School principal.

\subsection{SCHOOL CULTURE BASED}

According to Indonesian Ministry of Education and Culture (2017) the application of digital literacy competencies based on school culture can be applied in four major aspects, namely reading references, school activities, school policies, and school services. Citra Kasih High School as one of the schools that supports the School Literacy Movement (GLS), has implemented digital literacy competencies based on the school's culture.

\section{Reading Reference}

As one of the schools that supports the literacy movement, Citra Kasih High School also pays attention to the school library as one of the supporting facilities in literacy and learning activities for students. However, during this pandemic, the library seems to be paralyzed because all school members carry out the learning process at home. To overcome this, one of the efforts made by SMA Citra Kasih to continue to increase students' reading interest is to create a digital library.

Librarians look for some reading books in the form of e-books then download and classify them in folders according to certain themes. After that, each folder containing classified e-books is uploaded back to the school's google drive. The librarian then gives the google drive link to each homeroom teacher to be informed to students. Each student can search for the book they want through the given link. Of course, the available digital reading references are not as many as the number of books in the library, but they are enough to help students, especially students with high reading interest.

\section{Book Borrowing Frequency}

The search for borrowing digital themed books or digital books is one thing that is difficult to investigate in the application of digital literacy today. This is because face-to-face schools are not active so that the library does not operate, while the digital library provided does not contain as many books as those in the library, so it is very difficult for librarians to find out students' reading interest in reading references available in the library and difficult to know the frequency. limited borrowing of books. This condition becomes a big difficulty for librarians to know accurately how many students open or download books from the school's digital library.

\section{School Activity}

The Covid-19 pandemic that has occurred has forced students and teachers to study and do all activities at home to break the chain of virus spread. Therefore, according to the Principal of SMA Citra Kasih, all school activities are now digital which can be accessed from home. The school activities are not only teaching and learning processes, but also student activities. Recognizing the need for other activities to support students' skills, creativity, and character, the school made several student activities that were also carried out virtually. Some of the student activities that are carried out virtually are class meeting activities which are usually filled with sports activities, have now become electronic sports activities that are broadcast live on YouTube channels and school social media. Basic Student Leadership Training Activities (LDKS) which are usually carried out to train student leadership, have been replaced with Positive Character Day activities which are carried out to teach students to have character and have a positive attitude. To commemorate Easter Day, Citra Kasih High School also held a worship service attended by all Citra Kasih High School teachers and students which was carried out virtually without reducing the solemnity in worship. 


\section{School Policy}

School policies usually contain a series of decisions that become policies and regulations that must be carried out by school members. According to the Principal of Citra Kasih High School, there are many school policies related to the use and utilization of information and communication technology in the school environment, some of which are the freedom to use WIFI in the Citra Kasih High School area, the obligation to have personal digital devices, the teacher's obligation to follow and share in the TPD ( Teacher Personality Development) program which is conducted every month. This activity aims to develop teachers themselves and follow the development of digital evolution. The school understands teacher anxiety and supports teachers to develop their digital competencies. This is of course based on the capacity of different teachers and various subjects so that variations or sharing of knowledge that has been used or carried out in class is needed.

\section{School Service}

Citra Kasih High School always tries to utilize and apply information and communication technology in terms of school services. This has been done to make it easier for teachers to work and in providing optimal services to teachers and parents. Citra Kasih High School uses an independently managed system called CIS ( Ciputra Information System ) to manage classroom administration, process data and student grades and provide optimal service to students and teachers. This system is not only used in daily learning systems, such as processing grades, student attendance, weighting grades, setting student agendas and scheduling student tests, but can also be used in providing learning reports in the form of student daily scores and report cards of learning outcomes to parents on a regular basis. directly, so that parents can know the progress of students and learning outcomes can be accessed anytime and anywhere.

\section{Information Presentation}

The indicator of digital literacy related to the presentation of information is that schools present school information using digital media or web sites. All information about schools and school activities in general can be accessed on the website www.schoolcitrakh.sch.id . The information provided is in the form of school profiles, teacher profiles, facilities and infrastructure provided by schools, general school activities, and contact persons who can be contacted. This website is managed by the school as a whole.

In addition to utilizing the school website, Citra Kasih High School also uses several social media as publications for school activities such as YouTube, Instagram, Facebook, and Twitter which are managed by the Citra Kasih High School Intra-School Student Organization (OSIS). This social media is used as a means of presenting school information, media for publication of school activities, and means of communication with people outside of school.

\subsection{COMMUNITY BASED}

The last indicator of digital literacy competency based on Indonesian Ministry of Education and Culture (2017) reference is community based. Indicator of digital literacy competency based on community can be divided into two, they are the numbers of facilities and infrastructure and the involvement of parents, community, and institution.

\section{Facilities and Infrastructure}

As the principal mentioned before, the school really supports digital literacy applied in the school. Many facilities and infrastructure that the school has been provided to all the school members that support them. Computer laboratory that 
can be used during the school time, unlimited wifi that can be accessed freely by all students, teachers, and school staff. Printer, speaker, audio, LCD that can be used anytime needed. Since this pandemic, the school also has a temporary digital library that can be used by students. Schools always support the teachers and students with good facilities and infrastructure so all the activities will run smoothly without any problem.

\section{The Involvement of Parents, Community, and Institution}

Every year before the school starts a new academic year, the principal always sets up a meeting with parents and school community to talk about the program that the school will do. The purpose of the meeting is to inform and to get an insight from the parents and school community about the school program. Regarding digital literacy, the principal said that the parents support the school 100\%. The principal said that the parents will support the school by providing their children with the laptop that can be used during this online learning and also can be carried out to school someday. During the online learning, the parents also said that they will support their children with a good connection.

\section{CONCLUSIONS AND RECOMMENDATIONS}

Based on the discussion, it can be concluded that the practice of digital literacy based on Indonesia Ministry of Education and Culture digital literacy competency indicators have been carried out at Citra Kasih High School. The literacy praxis that is carried out in three bases, they are class based, school culture based, and community based.

The praxis of digital literacy based on class is implemented in digital literacy training, application and utilization of digital literacy, and in the use of digital media and internet. The praxis of digital literacy based on school culture at Citra Kasih High School is implemented in reading references, the frequency of borrowing books, school activities, school policies, school services and the presentation of information about Citra Kasih High School. Moreover, about community based, the digital literacy competencies indicator applied are facilities and infrastructure and the involvement of parents, community, and institution. A series of digital literacy competency practices are carried out complementary and mutually sustainable for the realization of effective and comprehensive school conditions and learning.

\section{ACKNOWLEDGEMENTS}

The researcher wants to say thank you very much to all supervisors from State university of Jakarta who guide the researcher to conduct this research. Thank you also to Citra Kasih School Principal and all teachers who are very kind and cooperative to share a lot of information needed in this research. As well to all relatives and family who always support the researcher to complete and finish this research.

\section{REFERENCES}

Bawden, D. (2001). Information and digital literacies: A review of concepts. Journal of Documentation, 57(2), 218-259. Retrieved from https://doi.org/10.1108/EUM0000000007083

Casey, L., Bruce, P. B. C., Martin, A., Reynolds, A., Shiel, D. G., Coffey, L., Brown, C., \& Hallissy, M. (2009) Digital Literacy in Primary Schools. Digital Literacy: New Approaches to Participation and Inquiry Learning to Foster Literacy Skills among Primary School Children. Education, 122. 
Ferrari, A., Punie, Yves \& Brečko, Barbara (2014). DIGCOMP: a Framework for Developing and Understanding Digital Competence in Europe. No.38. 3-17. Retrieved from http://www.openeducationeuropa.eu/nl/elearning_papers.

Kemendikbud (2017). Materi Pendukung Literasi Digital: Gerakan Literasi Nasional. Kementerian Pendidikan Dan Kebudayaan, 33. Retrieved from https://gln.kemdikbud.go.id/glnsite/wpcontent/uploads/2017/10/cover-materi-pendukung-literasi-finansialgabung.pdf

Kurniawati, N., Maolida, E. H., \& Anjaniputra, A. G. (2018). The praxis of digital literacy in the EFL classroom: Digital-immigrant vs digital-native teacher. Indonesian Journal of Applied Linguistics, 8(1), 28-37. Retrieved from https://doi.org/10.17509/ijal.v8i1.11459

Lathipatud Durriyah, T., \& Zuhdi, M. (2018) Digital Literacy With EFL Student Teachers: Exploring Indonesian Student Teachers' Initial Perception About Integrating Digital Technologies Into a Teaching Unit. International Journal of Education and Literacy Studies, 6(3), 53. Retrieved from https://doi.org/10.7575/aiac.ijels.v.6n.3p.53

Phuapan, P., Viriyavejakul, C., \& Pimdee, P (2016). An Analysis of Digital Literacy Skills among Thai University Seniors. IJet, 16(03).

Rodliyah, R. S. (2018). Vocational school EFL teachers' practices of integrating ICT into English lessons: Teachers' voices. Indonesian Journal of Applied Linguistics, $\quad 8(2), \quad 418-428 . \quad$ Retrieved from https://doi.org/10.17509/ijal.v8i2.13309

Supratman, L. P., \& Wahyudin, A (2017). Digital Media Literacy to Higher Students in Indonesia. International Journal of English Literature and Social Sciences, 2(5), 51-58. Retrieved from https://doi.org/10.24001/ijels.2.5.7 